
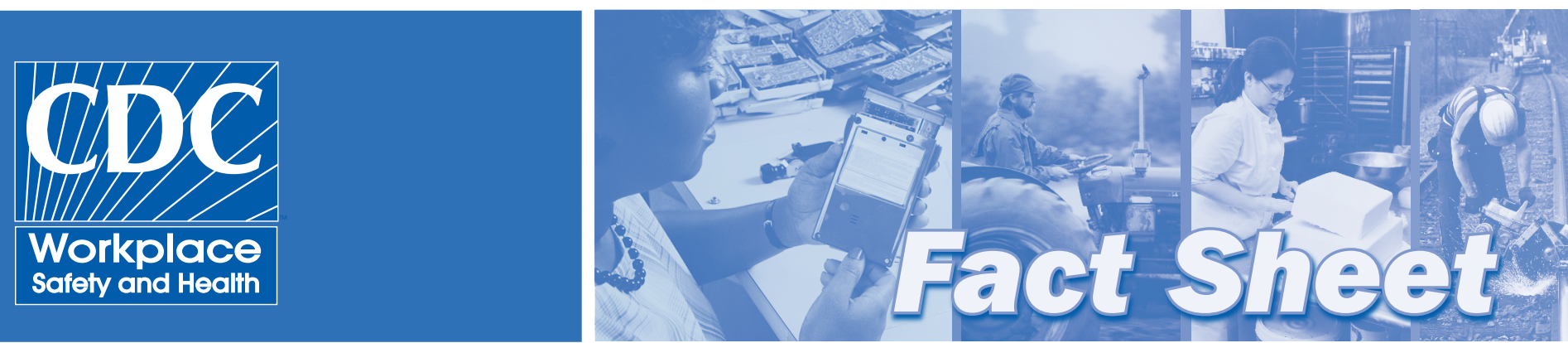

\title{
Mechanical Timber Harvesting Reduces Workers' Compensation Injury Claims in West Virginia
}

Logging is often considered the most dangerous occupation in the United States [BLS 2003]. Despite the risks, logging is a very important component of the wood products industry in West Virginia, which contributes approximately $\$ 1.4$ billion to the State economy each year [U.S. Census Bureau 1997; Hodgetts and Freese 2000].

\section{NIOSH Study}

Because of the high injury rate in logging, many State and Federal agencies as well as logger and industry groups have been working on ways to make logging safer. A recent study [Bell 2002] conducted by the Centers for Disease Control and Prevention's National Institute for Occupational Safety and Health (NIOSH) examined the injury claim rate among West Virginia logging companies over a 6-year period (1995-2000).

The study looked at the injury claim rate in 11 companies that used mechanized tree fellers. The overall injury claim rate for these companies was examined for about $21 / 2$ years before and about 2 years after

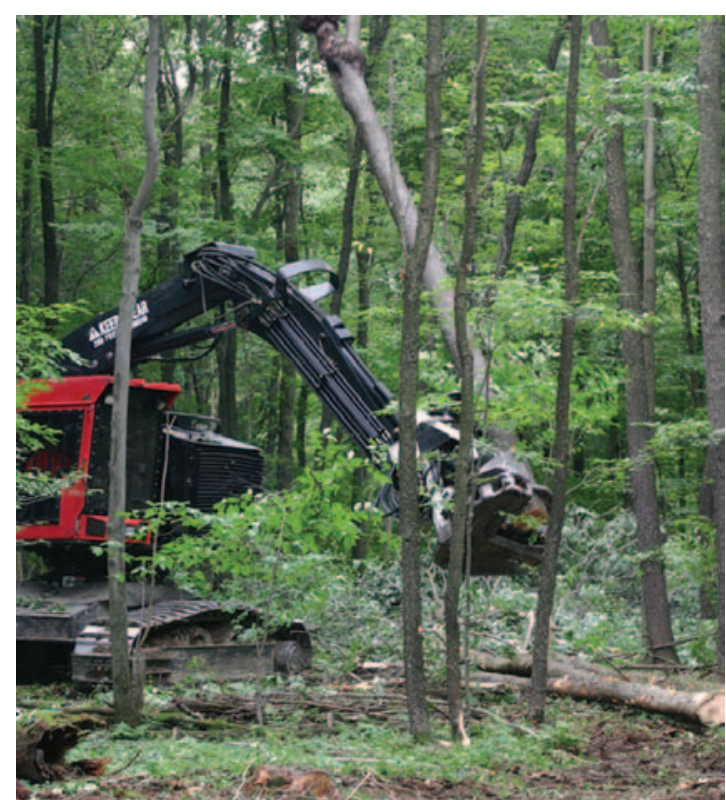

Feller Buncher

they started using mechanical felling machines. No decline in employment occurred after mechanization: the average number of workers per company was 5.2 before mechanical harvester use and 6.5 after.

The injury claim rate dropped significantly after mechanized felling began. The injury 
claim rate was 19.4 per 100 workers before mechanized felling (Figure 1, orange bar) compared with 5.2 per 100 workers after mechanized felling began (Figure 1, green bar). The injury claim rate for the rest of the West Virginia logging industry not using feller bunchers was 16.6 per 100 workers (Figure 1, blue bar).

The struck by an object injury claim rate also dropped from 10.1 per 100 workers before mechanization to 1.9 per 100 workers after mechanization. The decline in struck by injuries is especially important because these injuries tend to be the most serious (most fatalities are the result of a struck by injury).

\section{Mechanization and the Loggers' Safety Initiative}

NIOSH was also able to compare workers' compensation injury claim rates for 20 fully or partially mechanized companies and 68 nonmechanized (fully manual) companies participating in the West Virginia Loggers' Safety Initiative (LSI). This program provided training to these companies to reduce the frequency and severity of logging injuries. A company was considered to be mechanized if it was recorded as using a feller buncher during at least one LSI onsite inspection. The mechanized companies had an injury claim rate that was less than half that of the nonmechanized companies during the time they were in the LSI. This result demonstrates that mechanization can produce large reductions in injury claims, even within an LSI-trained group of loggers.

\section{Potential for Reducing Injury Claim Amounts}

During this study period, the average amount of a workers' compensation injury claim in the West Virginia logging industry was \$10,400. Companies not using feller bunchers during the study period had an injury rate of 16.6 per 100 workers, or 11.4 more injuries than the mechanized study group (5.2 per 100). Thus, assuming that the use of mechanical felling machines would be feasible for all companies not using feller bunchers and that the amount of an injury claim remained constant before and after mechanization, injury claims amounts could be reduced by $\$ 118,560$ per 100 workers. The number of

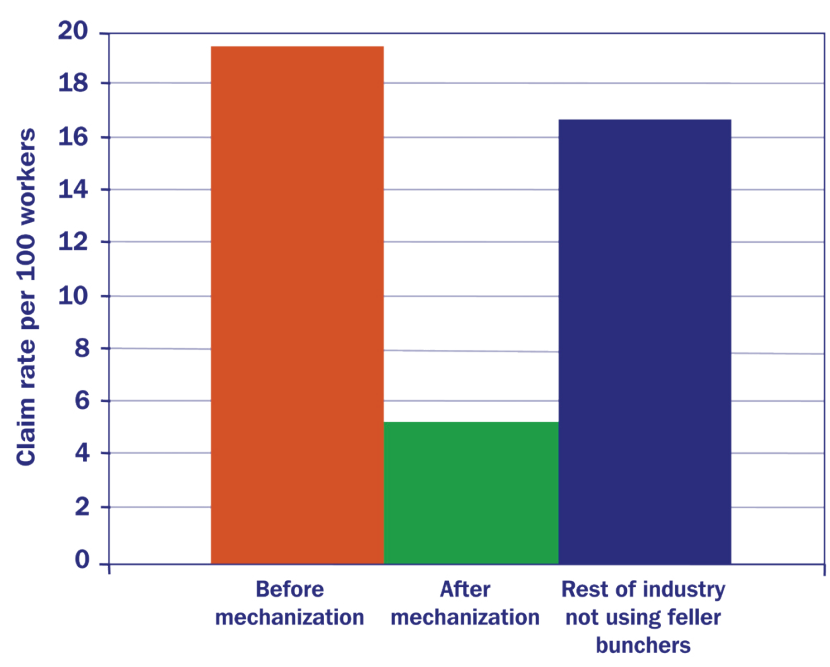

Figure 1. Workers' compensation injury claim rates before and after mechanized felling in West Virginia.

logging companies that could become mechanized is currently unknown. However, injury claim amounts could be reduced by about $\$ 900,000$ each year if $50 \%$ of the approximately 1,500 logging workers covered by the State workers' compensation system worked for a mechanized company. This amount reflects only potential injury claim reduction for the State workers' compensation system and is not meant to be an in-depth cost analysis.

\section{Summary}

Logging companies in West Virginia using mechanized harvesters had a significantly lower workers' compensation injury claim rate than did the rest of the West Virginia logging industry. Companies that were only partially mechanized (feller buncher plus chainsaw operators/fellers) still showed a significant reduction in the rate of injury claims. The use of mechanized fellers will be limited in some areas because of economic and other constraints such as the cost of purchasing fellers and the steepness of the terrain in West Virginia. However, the West Virginia logging industry as a whole may see substantial declines in injury claim rates if mechanized fellers are used whenever possible.

\section{References Cited}

Bell JL [2002]. Changes in logging injury rates associated with use of feller-bunchers in West Virginia. J Safety Res 33(4):463-471. 
BLS [2003]. Census of fatal occupational injuries. Washington, DC: U.S. Department of Labor, Bureau of Labor Statistics [www.bls.gov/iif/oshwc/ cfoi/cfch0002.pdf].

Hodgetts R, Freese R [2000]. An economic overview of the United States solid wood industry.
Washington, DC: U.S. Department of Agriculture, Foreign Agricultural Service [www.fas.usda.gov/ffpd/ economic-overview/overview.html].

U.S. Census Bureau [1997]. 1997 economic census [www.census.gov/epcd/www/econ97.html].

\section{For More Information}

To receive copies of the Journal of Safety Research article, copies of this fact sheet, or additional information, please visit the NIOSH Web site at www.cdc.gov/ niosh or contact us by telephone at $1-800-35-\mathrm{NIOSH}$ (1-800-356-4674). Or contact the following:

Jennifer L. Bell, Ph.D.

National Institute for Occupational Safety and Health

Division of Safety Research

1095 Willowdale Road, MS-1811

Morgantown, WV 26505-2888

Phone: 304-285-5802

E-mail: JBell@cdc.gov

or

Shawn T. Grushecky

West Virginia University

Appalachian Hardwood Center

P.O. Box 6125

Morgantown, WV 26506-6125

Phone: 304-293-2941, extension 2413

Email:sgrushec@wvu.edu

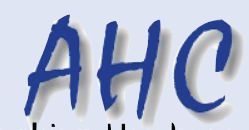

Appalachian Hardwood Center
To receive more information about occupational safety and health topics, contact NIOSH at

\section{$\mathrm{NIOSH}$}

Publications Dissemination

4676 Columbia Parkway

Cincinnati, OH 45226-1998

Telephone: 1-800-35-NIOSH (1-800-356-4674)

Fax: 513-533-8573・E-mail: pubstaft@cdc.gov

or visit the NIOSH Web site at www.cdc.gov/niosh

For a monthly update on news at NIOSH, subscribe to NIOSH eNews by visiting www.cdc.gov/niosh/ eNews.

This document is in the public domain and may be freely copied or reprinted.

Mention of any company or product does not constitute endorsement by the National Institute for Occupational Safety and Health (NIOSH). In addition, citations to Web sites external to NIOSH do not constitute NIOSH endorsement of the sponsoring organization or their programs or products. Furthermore, $\mathrm{NIOSH}$ is not responsible for the content of these Web sites.

Mechanical Timber Harvesting Reduces Workers' Compensation Injury Claims in West Virginia

DHHS (NIOSH) Publication No. 2005-129 


\section{Fact Sheet: Mechanical Timber Harvesting Reduces Workers' Compensation Injury Claims in West Virginia}

March 2005 • DHHS (NIOSH) Publication No. 2005-129

SAFER • HEALTHIER • PEOPLE

DEPARTMENT OF HEALTH AND HUMAN SERVICES

Centers for Disease Control and Prevention

National Institute for Occupational Safety and Health

4676 Columbia Parkway

Cincinnati, OH 45226-1998

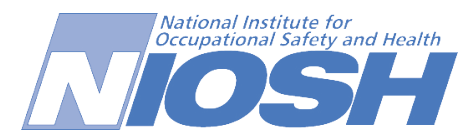

